\title{
GLL
}

$00=0$ Geomatics, Landmanagement and Landscape No. $2 \cdot 2019,37-54$

\section{SPATIAL DIVERSITY OF TOURISM ATTRACTIVENESS OF THE NOWY SĄCZ DISTRICT, USING THE WROCŁAW TAXONOMIC METHOD}

\author{
Krzysztof Gawroński, Karol Król, Grażyna Gawrońska, Natalia Leśniara
}

\begin{abstract}
Summary
Designation of areas that are attractive from the point of view of tourism is possible by assessing - among other things - the occurrence of tourist attractions in these areas, which become popular tourist destinations, as well as the presence of tourist infrastructure, which makes it possible to take full advantage of these assets. Such assessment can be made on the basis of statistical data analysis, carried out using taxonomic methods. The purpose of the study is to assess the spatial diversity of tourism attractiveness of the Nowy Sącz district (poviat), including the city of Nowy Sącz. The studies applied zeroed unitarization and Wrocław taxonomic method. It has been demonstrated that the majority of the municipalities in the Nowy Sącz district show similarities in terms of tourist attractiveness (according to the adopted research model).
\end{abstract}

\section{Keywords}

taxonomic methods $\bullet$ typology $\bullet$ ranking $\bullet$ socio-economic development

\section{Introduction}

The phenomenon of tourism is interdisciplinary, and representatives of many different scientific disciplines are investigating it - the fact, which testifies to its complexity and multidimensionality [Panasiuk 2006]. The so-called classic definitions of tourism include for instance the one developed by the World Tourism Organization (UNWTO). According to the aforementioned definition, "tourism covers the general activity of people who travel and stay - for leisure, business, and other purposes - for no more than one year without interruption, in places beyond their usual surroundings". This definition has been formulated in a general way, so that it can be used in the context of different views and different opinions on the phenomenon of tourism [Wodejko 1997]. Contemporary definitions and concepts of tourism, in addition to taking into account its cognitive, entertainment, sport or recreational value, draw attention to the economic aspect that is important in the market economy. They point to the fact that tourists earn and spend their money, both while travelling and while staying temporarily in the places they travel to [Sikora 2012]. 
Tourism can be considered on many levels. It is simultaneously a psychological, social, cultural, spatial and economic phenomenon [Przecławski 2000, Alejziak 2000]. In 1995, the World Tourism Organization determined that the basic unit of measurement in tourism is the number of visitors. The visitors are all those people who travel to places outside their everyday surroundings and stay there for no longer than a year. These journeys can be motivated by recreational purposes, they can be related to work or other needs, and they can take place in the country of permanent residence or abroad. Among all visitors, one-day visitors and tourists are distinguished from the people who spend at least one night in the city or country they visit. These overnight stays take place in collective or individual accommodation facilities, which belong to private persons or companies or are state owned (public) [Sikora 2012].

As persons who take part in travels and satisfy their needs through the consumption of specific tourism goods and services, tourists constitute the main party that generates and shapes demand on the tourism market. The market also comprises of people who produce and offer particular tourism goods or services, as well as socio-economic relations aimed at establishing exchange and sale transactions.

\section{Tourism supply and demand}

Tourism demand can be defined as the "demand for a certain amount of tourism goods and services, which tourists are willing to purchase at a given price level in order to meet their needs related to the tourist movement" [Gołembski 2005]. Tourism demand can be considered in terms of many criteria. Taking into account the purchasing power of the participants, we distinguish the potential and the actual (also called effective) demand in the tourism market. Potential demand is any demand that would be reported for tourism goods and services if the buyers had unlimited resources and could allocate these resources to meet all their tourism needs. In turn, the actual demand relates to these tourism goods and services that can be realistically purchased, as the buyer has the financial means to satisfy them [Kurek 2008].

Many factors influence tourism demand, including the economic, social, psychological and supply aspects. In the modern world, these factors are characterized by rapid dynamics of change [Middleton 1996]. An important factor that impacts the size of tourism demand comes from economic variables occurring in countries and regions where potential tourists live. The increase in the average income, which remains at the disposal of one inhabitant, increases the demand for tourism goods and services. The price of goods and services also has a large impact on the volume of demand - usually when the prices increase, the demand falls, and when the prices fall - then the demand increases. This correlation can be observed in recreational tourism [Gaworecki 2010]. However, there is a big difference in the dimension and structure of tourism demand compared for the demand in the place of the tourist's permanent residence. As a rule, the tourist is willing to spend more money when travelling rather than in the area where he lives [Panasiuk 2006]. Tourism supply remains in close connection with tourism demand and it is the sum of all goods and services that are offered on the tourism 
market and that have their specific prices. Supply can be characterized as a component of primary and secondary supply. Primary supply consists of all natural tourism assets, social and cultural relations, as well as technical infrastructure and complementary goods that can be used by the local community. The components of the secondary supply are these institutions and facilities of tourism infrastructure, which constitute the material and organizational base for tourism services [Gaworecki 2010].

Supply has its own characteristic properties. It is not very flexible, because tourism assets do not move; and it is also ephemeral, which means that the given offer must be sold on a specific day, or otherwise the income that could be obtained from it will be lost. Also, no tourism goods and services can be stored. The services require direct contact with the recipient, and their production takes place at the exact time and place of their consumption [Sikora 2012].

\section{Tourism traffic}

An important concept that refers to the phenomenon of tourism is tourism traffic, which can be defined as voluntary and temporary travel using various means of transport, and which is supported by various motivations for travel. It is caused by tourists' needs (the demand for tourism goods and services) and the production of services that meet these needs (the supply) [Sikora 2012]. Tourism traffic mainly affects the economic and social spheres, and its impact intensifies when the tourism traffic increases [Panasiuk 2006].

The division of tourist traffic is a complex issue, because there are many different classification possibilities. From the point of view of tourism traffic services, a classification grouping the criteria for the division of tourism traffic into those describing a tourism trip and its participants seems to be the most comprehensive and most significant [Wodejko 1997].

Taking additionally into account the purpose of the journey and its duration, the following are distinguished: stationary tourism (for instance, holidays, health holidays, summer camps, special camps), transient tourism (for instance, tourist and sightseeing trips, special tours) as well as transient tourism and holiday traffic [Borne 1998]. Four basic components can also be adopted as a criterion for the subdivision. These are: the area where tourism is cultivated (domestic, international), the duration of the trip depending on the leisure time of the tourist (stays, tours, weekend trips), intensity of tourist services (individual or organized trip) and the degree to which specialist equipment and clothing is used (qualified - "adventure tourism" and non-qualified tourism) [Szubert-Zarzeczny 2002].

\section{Tourism economy}

Tourism economy is a collection of various social and economic functions that, when developed directly or indirectly, contribute to the satisfaction of human needs relating to tourism goods and services. Tourism economy can therefore be an important factor 
influencing the shaping of economic and social policy. The increase of various activities in the field of tourism economy leads to a better service and to raising standards in tourism traffic [Gaworecki 2010]. Tourism economy is visible in each of the sectors of the economy, which refer to the processes of creating goods and services, their division, exchange or consumption. It also manifests itself in all branches of the national economy, which in any way relate to tourism demand, and affect its size. However, it is not an independent sector of the economy, such as construction, transport or healthcare [Kornak 1997].

In the tourism economy, there is a relationship between tourists who have different needs, and institutions or organizations that meet these needs. This may concern, for example, the adaptation of the natural environment for visitors, and carrying out activities aimed at the development of these areas. Therefore, the tourism economy system is closely connected with tourism demand, and the latter shapes the type, size and character of the former. It is the demand that the activities undertaken in the tourism economy depend upon [Panasiuk 2008].

A typical tourism economy includes enterprises, institutions or organizations offering services exclusively for people traveling. These include hospitality (hotel and gastronomy) and transportation services, including the organization of congresses, seminars, fairs, travel agent activities, spas, management boards of tourism municipalities, etc. The complementary tourism economy is made up by those enterprises, tourism institutions and organizations that belong to many different sectors or branches of the economy. In their activity, one can distinguish groups of services that are necessary or important in the implementation of travel, such as editorial houses that publish guidebooks, tourist magazines, and maps, travel insurance brokers, currency exchange bureaus, etc. [Łazarek 1999].

Indirect tourism economy (atypical tourist activity) includes the activity of business entities that meet the needs of various social groups. They do not constitute characteristic or standard tourism products, and their presence in the economy is not strongly dependent on tourism, because various groups of consumers use it. It may happen, however, that due to the large scale of tourism traffic and the seasonality of tourism, the liabilities towards tourists prevail [Panasiuk 2008]. Seasonality also affects entities that occupy a lower position in the structure of the tourism economy. They often have to adapt their offer so that after the tourist season, the population living in the given area can use it as well [Gaworecki 2010].

Tourism enterprises constitute the main element in the tourism economy structure. These are deliberately organized, materially independent, separate (in legal, spatial, technical and service terms) groups of people with financial resources and capital. They are established in order to perform specific activities, mainly providing tourism services aimed at satisfying the needs (also living, welfare needs) of the visitors. This activity must also bring benefits to the enterprise [Rapacz 1994]. The impact of tourism enterprises' activities is also felt by the inhabitants of the areas where the tourism product is created. The latter often combines the service offer of various companies and tourism institutions, including hotels, catering, transportation, etc. [Rapacz 1998]. 
Another subject or party to the tourist economy is the territorial self-government and its units, which simultaneously constitute an element of the public administration of the country, and bring together the community of citizens. They ensure the proper functioning of the economy, since many local activities depend on them. These units are responsible for providing access to tourist information (including proper marking of tourist routes and other attractions of the region) and public transport means, creating and maintaining local technical infrastructure, cooperation with organizations, enterprises and institutions from the tourism industry, and so forth. Through appropriate legal provisions, local self-government influences the development of local and regional tourism products, stimulation of the local economy (including tourism), and creation of new jobs [Panasiuk 2008].

\section{Tourism as a determining factor of local development}

The development of tourism, especially in more developed tourist regions, contributes to many transformations and progressive changes. An important element of the impact of tourism on particular areas and territories is the stimulation of various types of location processes. However, the development of tourist areas is not limited to this type of processes, because it consists of the entire area strictly related to all kinds of social or economic activity, which is dependent on tourism [Meyer and Milewski 2009]. In regional terms, tourism can be a polarizing factor, a stimulating factor, or a neutral factor for the development of the region [Kornak and Rapacz 2001].

The polarizing effect of tourism is typical for areas characterized by high tourist attractiveness. In these areas, apart from the developed infrastructure and high tourism attractiveness, conditions prevail that are conducive to the development of many other sectors of the economy. The functioning of these sectors, in an indirect or direct way, depends on the phenomenon of tourism in the given area, and it affects the increase in tourism and the sphere of its service. The activities of the tourism and para-tourism economy are closely related, which means that the development of all economic areas in the region is determined by tourism. In turn, the stimulating effect of tourism on the socio-economic development of the region is typical for areas where tourism has only an indirect impact on the economy. There are other sectors functioning there, which have a more dominant significance. The neutral significance of tourism occurs in areas where tourism does not have a significant impact on socio-economic development, but is only a complementary activity [Kornak and Rapacz 2001].

The amplification of the region's wealth, which in turn translates into the development of the area and increase in the standard of living of the population that inhabits it, may be considered the most common positive consequence of the development of tourism in the region. Larger incoming numbers of tourists with specific needs require appropriate preparation: provision of new services, construction or modernization of the existing tourist infrastructure (accommodation facilities, theme parks, etc.) as well as para-tourism infrastructure (service points, catering facilities, technical infrastructure facilities and others) [Meyer and Milewski 2009]. Thus, the devel- 
opment of tourism influences the change of the situation on the local labour market, in the infrastructure system or the region's budget. In tourist areas, there is increased demand for employees in many industries, such as hospitality industry (hotels or restaurants). Also, completely new professions are created, related to the tourism movement, such as a tour guide or an interpreter [Wodejko 1997]. The growth in the number of people employed is caused not only by the necessity of servicing tourists, but also by the development of investment projects aimed at extending the existing infrastructure or building the new one. In addition to employees, tourism services or other investment projects also require a specific package of services or goods, without which it would be impossible to take any action. The demand for services and goods is also caused by the increase in the employment - not only does it lead to a drop in unemployment, but also to an increase in the incomes of the local population, who may benefit from a greater number of goods [Meyer and Milewski 2009]. The increase in the number of visitors to the region leads to an increase in that region's revenues. The transfer of cash is made, from places of permanent residence of the tourists to the destinations they visit. The revenues from the tourism sector to the regional budget are largely made up of tourists' expenses, travel services, transport services provided by local carriers, activities of other local business entities whose operation is directly or indirectly linked to tourism, as well as the incomes of the local population [Gołembski 2007]. The increase of local revenues allows financing further social and economic investments related to the services and communal infrastructure intended for the benefit of both the local community and the tourists (mainly road infrastructure, protection of the natural environment, etc.) [Meyer and Milewski 2009] Tourism also contributes to changes in the local socio-cultural environment. Persons employed in the tourism sector are required to be able to handle and operate tourism facilities, learn about the principles of quality customer service, or acquire foreign language skills. This enforces the increase in the qualifications and competences of the employees, and thus raises the economic culture of the society. The knowledge advancement, as well as the openness to new people and their culture, are additional factors of social and economic progress, which facilitate the integration of the communities inhabiting the tourism destination with the world. Tourism also impacts the tourists themselves who, when visiting a given area, experience some positive effects: they gain knowledge, broaden their intellectual horizons, establish friendly contacts, as well as learning tolerance and openness to different customs and cultures [Meyer and Milewski 2009]. Positive aspects of tourism may also refer to the natural environment. Often, in order to be able to use the existing natural tourism assets, it is necessary to introduce protective measures. Without them, these assets may often become damaged or completely destroyed. Over the years, the growing environmental awareness (among tourism organizers, as well as tourism participants) and the awareness of the importance of natural assets for tourism often leads to the situation where it is tourism that initiates activities for the protection of the natural environment. These activities can be conducted on many levels: legal, economic, technical, technological and organizational. 


\section{Material and methods}

Distinguishing the areas that are particularly attractive from tourism point of view is possible by assessing the occurrence in these areas of tourist attractions, which are the destination of tourist arrivals and tourism infrastructure, while the latter makes it possible to take full advantage of these assets. Such assessment can be made on the basis of statistical data analysis carried out using taxonomic methods [Prus et al. 2018].

The goal of the present study is to assess the spatial diversity of the tourist attractiveness of the Nowy Sącz district (poviat) including the city of Nowy Sącz. Nowy Sącz district (powiat Nowosądecki) together with the city of Nowy Sącz is located in the south-eastern part of the Małopolska region (Poland). The southern border of the district doubles as the border of the Polish state (Fig. 1).

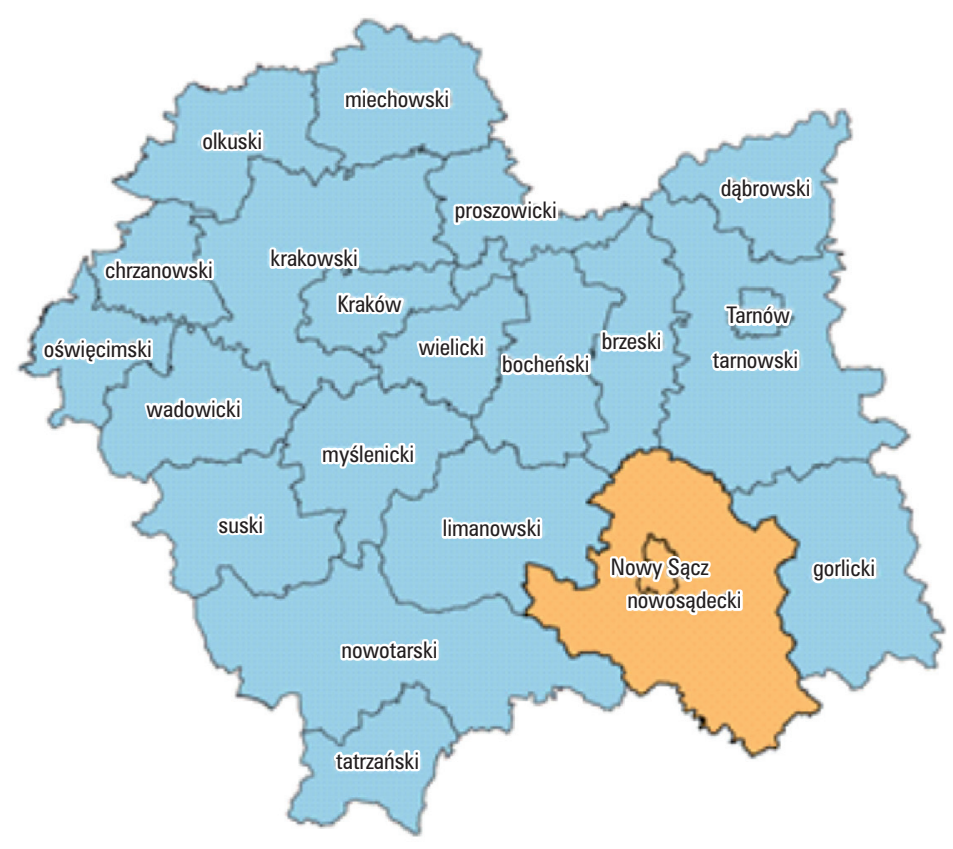

Source: authors' own study

Fig. 1. Location of the Nowy Sącz district within the Małopolska region

Nowy Sącz district consists of 16 basic-level administrative units (municipalities), which are: Chełmiec, Gródek nad Dunajcem, Grybów, Kamionka Wielka, Korzenna, Krynica-Zdrój, Łabowa, Łącko, Łososina Dolna, Muszyna, Nawojowa, Piwniczna Zdrój, Podegrodzie, Rytro, Stary Sącz, and the city of Grybów (Fig. 2). 


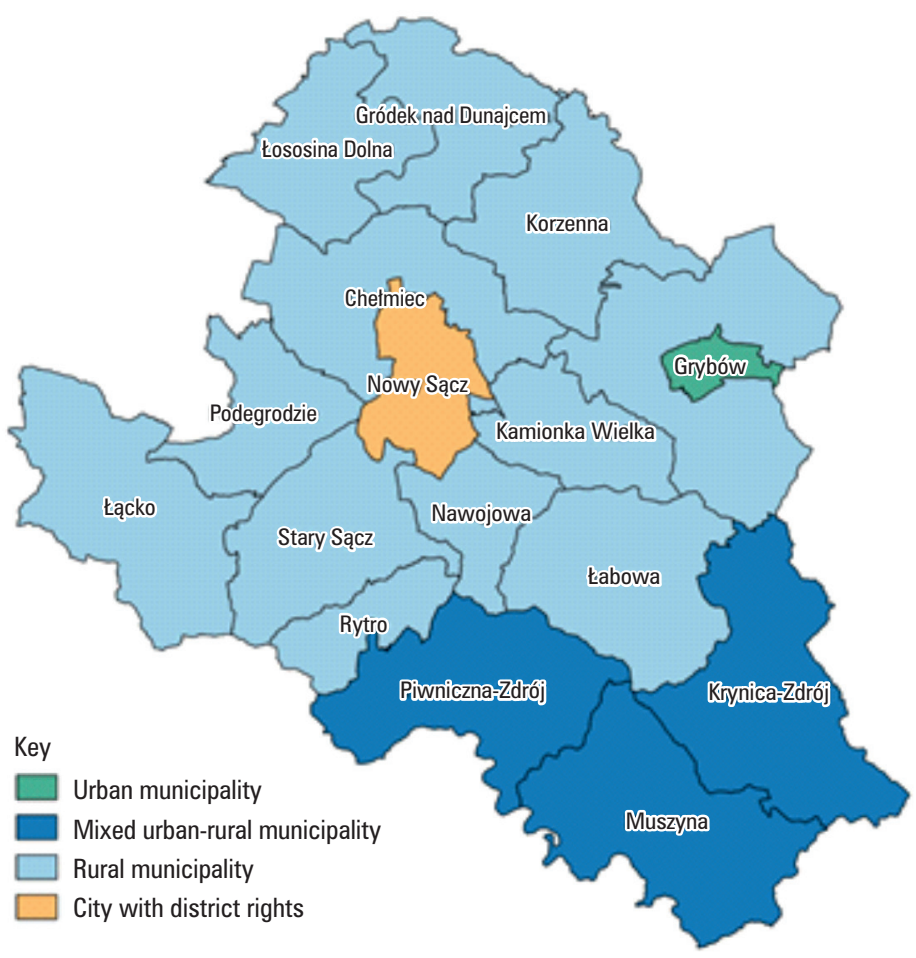

Source: authors' own study

Fig. 2. Administrative division of the Nowy Sącz district

Zeroed unitarization was used to normalize the variables. The taxonomic analysis was performed using the Wrocław taxonomic method [Gawroński et al. 2014]. The main reason for conducting taxonomic analyses is the assessment of the level of diversity between the objects, which form the initial set of statistical data, and the determination of similarity between these objects by determining clusters. An equally important and inherent element of the analysis consists in creating classes of objects that are homogeneous in terms of their characteristics. Performing the taxonomic analysis also contributes to the expanding and advancement of knowledge about the studied phenomenon or area, as it facilitates an assessment of the contribution or impact of a given element on the development of the entire population, as well as enabling the creation of a graphic visualization of the problem under investigation [Młodak 2006, Wysocki 2010].

Normalization of variables is a preliminary activity, in which we are preparing the empirical material for further research. After adding together the standardized values of the features, normalization allows us to determine gradations and classes of the examined objects. In this way, it is possible to determine the scale of spatial differ- 
entiation, taking into account the use of any method for classifying objects, as well as to determine which of the studied regions are described by the best, and which by the worst indicators. The method of zeroed unitarization, which uses the maximum and the minimum values of the diagnostic features, was selected here as a method for the normalization of variables [Król and Prus 2018]. Considering that the variables adopted for the analysis were of varying character, in the unitarization process, one formula (1) was applied for the stimulant variables $(S)$, and another formula (2) was used for the deterrent variables $(D)$.

$$
\begin{aligned}
& z_{i j}=\frac{x_{i j}-\min _{i}\left\{x_{i j}\right\}}{\max _{i}\left\{x_{i j}\right\}-\min _{i}\left\{x_{i j}\right\}} \\
& z_{i j}=\frac{\max _{i}\left\{x_{i j}\right\}-x_{i j}}{\max _{i}\left\{x_{i j}\right\}-\min _{i}\left\{x_{i j}\right\}}
\end{aligned}
$$

where:

$i=1,2, . ., n ; j=1,2, \ldots, m$,

$z_{i j} \quad-\quad$ standardized diagnostic variable,

$x_{i j} \quad-$ non standardized diagnostic variable,

$\min _{i}\left\{x_{i j}\right\}$ - the minimum value of the non standardized diagnostic variable,

$\max _{i}\left\{x_{i j}\right\}$ - the maximum value of the non standardized diagnostic variable.

The Wrockaw taxonomic method was developed at the beginning of the 1950s by the Application Group of the National Mathematical Institute in Wrocław. In 1949, Kazimierz Florek developed a method of combining a set of points on a plane. The concept was closely related to the method developed by Jan Czekanowski. Julian Perkal constructed the Wrocław dendrite, while Stefan Zubrzycki and Jan Łukasiewicz were the proponents of the Wrockaw division. In turn, the dual dendrite was created by Hugo Steinhaus [Grabiński et al. 1989].

The Wrocław taxonomic method belongs to hierarchical grouping methods. In this method, a dendrite is built by combining each subsequent unit with the most similar unit. In this way, so-called first-degree connections are formed. If as a result of that procedure, not all elements of the set are combined, then the individual subsets should be merged into one dendrite by directly connecting them with a line of elements of the different subsets that are most similar to each other. In this way, second-degree connections are determined. The basic assumption of dendritic grouping is to meet the condition stating that the dendrite connecting the points (units) in the n-dimensional space is as short as possible, without creating a cycle [Heffner and Gibas 2007]. 


\section{Spatial analysis of the variability of tourism attractiveness of Nowy Sącz district, including the town of Nowy Sącz}

In every comparative analysis, which is multidimensional in character, at the beginning of the research it is necessary to define the studied object and the set of attributes characterizing the properties of this object, i.e. the diagnostic variables. The correct selection of diagnostic variables can have a significant impact on the research results, regardless of the methods and techniques used. Incorrect selection of variables may lead to incorrect comparative analysis results. A significant number of variables that characterize objects in multidimensional comparative analyses make it necessary to select the most important variables from the point of view of the studied phenomenon [Panek 2009]. Excessive broadening of the set of variables may contribute to the inclusion of irrelevant information in the study. One should also avoid biased selection of variables, that is one confirming the presupposed hypothesis [Frankowski 1991].

The condition for the correct selection of the initial list of diagnostic variables is a thorough knowledge of the subject of the research. Knowledge of both economics in general and the particular industries, as well as the researcher's experience or even intuition can be important in this matter. The diagnostic variables taken into account must result from obvious substantive connections with the phenomenon being the subject of research [Zeliaś 2000].

A statistical data bank was created for the needs of the study. These data describe the situation in the area of Nowy Sącz district and the city of Nowy Sącz at the end of 2015, and they include diagnostic features that affect the existence or development of tourism, and thus the tourism function that these areas perform. At the same time, the following assumptions were made: that municipality would be adopted as the basic unit of research, and the statistical material would be obtained from the Local Data Bank.

The preliminary set of diagnostic variables was collated after the substantive and formal analysis of variables. After analysing the available data, a set of 26 potential diagnostic features was selected. The numerical values of these variables are presented in Table 1. They describe the city of Nowy Sącz and all the municipalities included in the Nowy Sącz district.

When analysing the diagnostic variables, we notice their considerable variation let us consider, for example, the number of stadiums, halls, sports fields (X9) or the existing "nature monuments" (X15). The variables have often assumed zero values, which occurred mainly in the case of characteristic features, depending, for example, on natural conditions or the possibilities of a given region. It is not in any given municipality that the local conditions would allow creation of ski stations or ski lifts (X6), or yachting or canoeing clubs $(X 7)$.

All the potential diagnostic variables have been subjected to a verification process, taking into account their information capacity. The parametric method was used in this case. A correlation matrix between potential diagnostic features was determined. The correlation matrix made it possible to calculate the threshold value of the correlation coefficient, which in subsequent stages allowed us to determine the diagnostic central variables and isolated variables. 


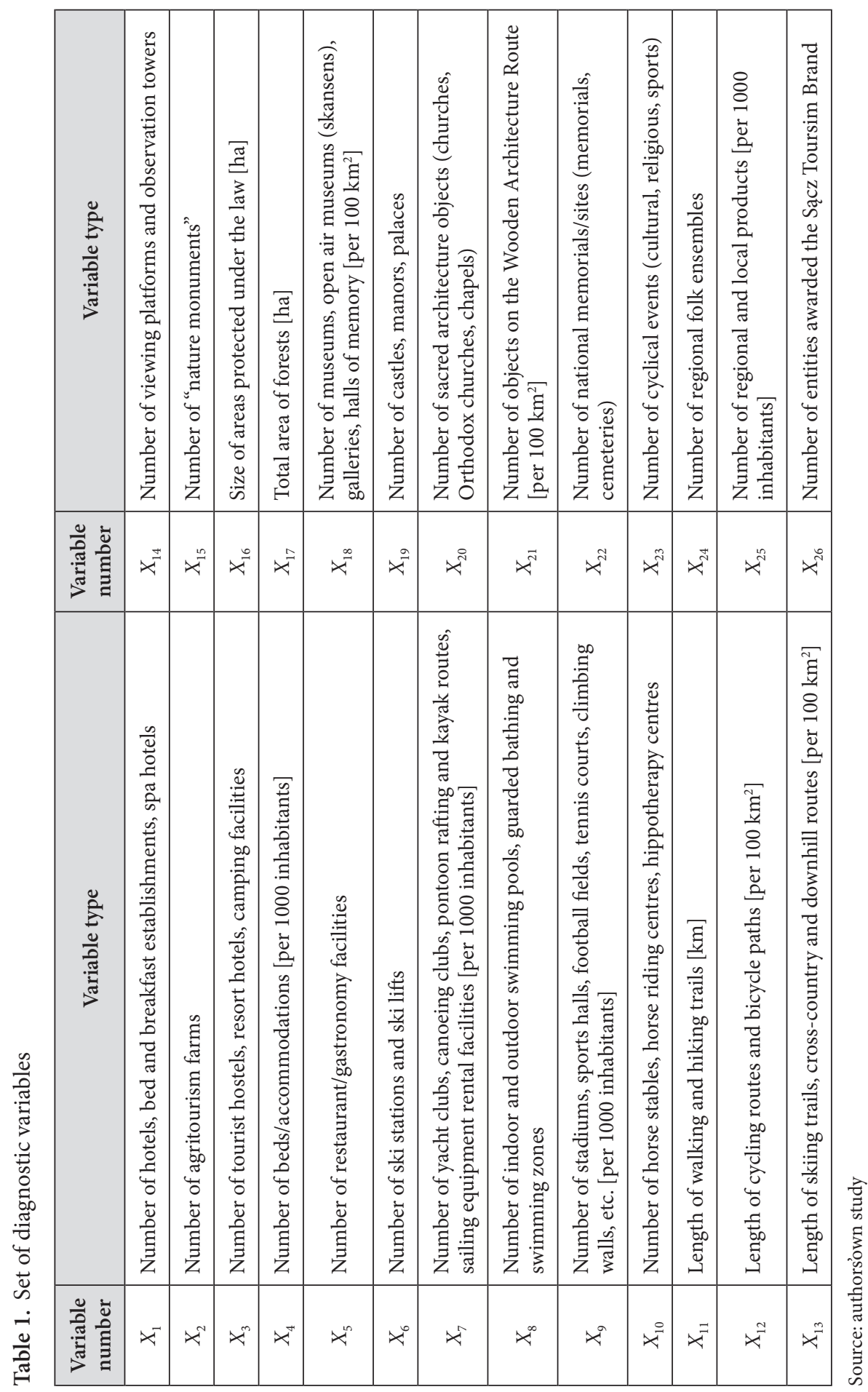


The next step was to select the ultimate list of diagnostic variables. This was done using the Hellwig method in which, after taking into account the sum of absolute values in the rows/columns of the correlation matrix, and the known threshold value of the correlation coefficient, central variables and the corresponding satellite variables were found. The remaining variables that did not create a cluster - the so-called isolated variables - also constitute diagnostic features adopted for further research (Table 2).

Table 2. Set of diagnostic variables adopted for the analysis

\begin{tabular}{|c|c|c|c|}
\hline $\begin{array}{l}\text { Variable } \\
\text { number }\end{array}$ & Variable type & $\begin{array}{l}\text { Variable } \\
\text { number }\end{array}$ & Variable type \\
\hline$X_{4}$ & $\begin{array}{l}\text { Number of beds/accommodations } \\
\text { [per } 1000 \text { inhabitants] }\end{array}$ & $X_{16}$ & $\begin{array}{l}\text { Size of areas protected under the law } \\
\text { [ha] }\end{array}$ \\
\hline$X_{7}$ & $\begin{array}{l}\text { Number of yacht clubs, canoeing } \\
\text { clubs, pontoon rafting and kayak } \\
\text { routes, sailing equipment rental } \\
\text { facilities [per } 1000 \text { inhabitants] }\end{array}$ & $X_{18}$ & $\begin{array}{l}\text { Number of museums, open air } \\
\text { museums (skansens), galleries, halls } \\
\text { of memory [per } 100 \mathrm{~km}^{2} \text { ] }\end{array}$ \\
\hline$X_{9}$ & $\begin{array}{l}\text { Number of stadiums, sports halls, } \\
\text { football fields, tennis courts, climbing } \\
\text { walls, etc. [per } 1000 \text { inhabitants] }\end{array}$ & $X_{21}$ & $\begin{array}{l}\text { Number of objects on the Wooden } \\
\text { Architecture Route [per } 100 \mathrm{~km}^{2} \text { ] }\end{array}$ \\
\hline$X_{12}$ & $\begin{array}{l}\text { Length of cycling routes and bicycle } \\
\text { paths [per } 100 \mathrm{~km}^{2} \text { ] }\end{array}$ & \multirow{2}{*}{$X_{25}$} & \multirow{2}{*}{$\begin{array}{l}\text { Number of regional and local } \\
\text { products [per } 1000 \text { inhabitants] }\end{array}$} \\
\hline$X_{13}$ & $\begin{array}{l}\text { Length of skiing trails, cross-country } \\
\left.\text { and downhill routes [per } 100 \mathrm{~km}^{2}\right]\end{array}$ & & \\
\hline
\end{tabular}

Source: authors'own study

The procedure for determining the weights of diagnostic variables was conducted on the basis of the BVP formula, which takes into account the components of discriminatory capacity and the components of information capacity. When multiplying these two features, the variables' weights were obtained (Table 3 ).

Table 3. Weights of the diagnostic variables

\begin{tabular}{|c|c|c|c|}
\hline Variables & $\begin{array}{c}\text { Components } \\
\text { of discriminatory capacity }\end{array}$ & $\begin{array}{c}\text { Components } \\
\text { of information capacity }\end{array}$ & Variables' weights \\
\hline$X_{4}$ & 0.1365 & 1.2719 & 0.1736 \\
\hline$X_{7}$ & 0.1082 & 1.3276 & 0.1436 \\
\hline$X_{9}$ & 0.0727 & 1.2366 & 0.0899 \\
\hline$X_{12}$ & 0.1874 & 1.3021 & 0.2440 \\
\hline$X_{13}$ & 0.1552 & 1.4214 & 0.2206 \\
\hline$X_{16}$ & 0.0405 & 1.3063 & 0.0529 \\
\hline
\end{tabular}




\begin{tabular}{|l|l|l|l|}
\hline$X_{18}$ & 0.1060 & 1.3531 & 0.1434 \\
\hline$X_{21}$ & 0.0716 & 1.3034 & 0.0217 \\
\hline$X_{25}$ & 0.1218 & 1.3904 & 0.1694 \\
\hline
\end{tabular}

Source: authors' own study

By far the largest weights were obtained for three variables: $X_{12}$ (length of cycling routes and bicycle paths [per $100 \mathrm{~km}^{2}$ ]), $X_{13}$ (length of skiing trails, cross-country and downhill routes [per $100 \mathrm{~km}^{2}$ ]) and $X_{4}$ (number of beds/accommodations [per 1000 inhabitants]). These, therefore, are the variables that have the greatest impact on the diversity of the tourist attractiveness of the Nowy Sącz district.

Normalization of diagnostic variables

The obtained diagnostic features were re-analysed in terms of their impact on the development of tourism in the area of Nowy Sącz district and the presence of the tourism function. It was established that all diagnostic features are stimulants. The results of the normalization of variables are presented in Table 4.

Table 4. Values of diagnostic variables after performing zeroed unitarization

\begin{tabular}{|l|c|c|c|c|c|c|c|c|c|}
\hline \multicolumn{1}{|c|}{ Municipality } & $X_{4}$ & $X_{7}$ & $X_{9}$ & $X_{12}$ & $X_{13}$ & $X_{16}$ & $X_{18}$ & $X_{21}$ & $X_{25}$ \\
\hline Nowy Sącz (town) & 0.006 & 0.000 & 0.176 & 0.008 & 0.000 & 0.050 & 1.000 & 0.500 & 0.000 \\
\hline Chełmiec & 0.019 & 0.000 & 1.000 & 1.000 & 0.000 & 1.000 & 0.680 & 0.500 & 0.221 \\
\hline Gródek nad Dunajcem & 0.115 & 1.000 & 0.118 & 0.049 & 0.000 & 0.542 & 0.120 & 0.500 & 0.000 \\
\hline Grybów (town) & 0.026 & 0.000 & 0.118 & 0.000 & 0.000 & 0.000 & 0.120 & 0.000 & 0.059 \\
\hline Grybów & 0.004 & 0.000 & 0.000 & 0.015 & 0.042 & 0.466 & 0.120 & 0.500 & 0.088 \\
\hline Kamionka Wielka & 0.016 & 0.000 & 0.235 & 0.221 & 0.040 & 0.694 & 0.160 & 0.500 & 0.118 \\
\hline Korzenna & 0.002 & 0.000 & 0.000 & 0.004 & 0.000 & 0.050 & 0.000 & 0.000 & 0.000 \\
\hline Krynica-Zdrój & 1.000 & 0.250 & 0.588 & 0.010 & 0.560 & 0.694 & 0.200 & 1.000 & 0.015 \\
\hline Łabowa & 0.040 & 0.000 & 0.176 & 0.023 & 0.013 & 0.694 & 0.000 & 0.000 & 0.015 \\
\hline Łącko & 0.023 & 0.250 & 0.059 & 0.093 & 0.000 & 0.694 & 0.000 & 0.000 & 0.162 \\
\hline Łososina Dolna & 0.025 & 0.875 & 0.059 & 0.013 & 0.000 & 0.694 & 0.080 & 0.500 & 0.000 \\
\hline Muszyna & 0.629 & 0.875 & 0.941 & 0.026 & 0.164 & 0.694 & 0.080 & 1.000 & 0.029 \\
\hline Nawojowa & 0.063 & 0.000 & 0.059 & 0.015 & 0.000 & 0.694 & 0.120 & 0.000 & 0.147 \\
\hline Piwniczna-Zdrój & 0.272 & 0.500 & 0.176 & 0.031 & 1.000 & 0.694 & 0.120 & 0.000 & 0.015 \\
\hline Podegrodzie & 0.000 & 0.000 & 0.000 & 0.006 & 0.000 & 0.358 & 0.280 & 0.500 & 0.221 \\
\hline Rytro & 0.407 & 0.875 & 0.824 & 0.032 & 0.123 & 0.694 & 0.120 & 0.000 & 1.000 \\
\hline
\end{tabular}

Source: authors' own study 
The procedure of zero unitarization facilitated bringing the values of diagnostic features to their mutual comparability. After ranking the municipalities in terms of the value of the aggregated index, the initial diversification of the areas in terms of tourism attractiveness and availability of tourism infrastructure, contributing to the development of tourism has been established (Table 5).

Table 5. Combined normalised values for particular municipalities

\begin{tabular}{|l|l|}
\hline \multicolumn{1}{|c|}{ Municipality } & Aggregated index value \\
\hline Muszyna & 4.439 \\
\hline Chełmiec & 4.420 \\
\hline Krynica-Zdrój & 4.318 \\
\hline Rytro & 4.075 \\
\hline Piwniczna-Zdrój & 2.809 \\
\hline Gródek nad Dunajcem & 2.443 \\
\hline Łososina Dolna & 2.246 \\
\hline Kamionka Wielka & 1.983 \\
\hline Stary Sącz & 1.890 \\
\hline Nowy Sącz (town) & 1.740 \\
\hline Podegrodzie & 1.364 \\
\hline Łącko & 1.281 \\
\hline Grybów & 1.236 \\
\hline Nawojowa & 1.098 \\
\hline Łabowa & 0.962 \\
\hline Grybów (town) & 0.322 \\
\hline Korzenna & 0.056 \\
\hline
\end{tabular}

Source: authors'own study

When analysing the gradation of municipalities, we notice a substantial variation in the values obtained, which justified the continuation of research and the creation of groups of municipalities that were similar to each other in terms of tourism development. The largest total of normalized values was recorded in the municipalities of Muszyna, Chełmiec, Krynica-Zdrój and Rytro, while the lowest values were calculated for the Łabowa municipality, the city of Grybów and the Korzenna municipality. These municipalities exhibit the lowest level of tourism development among all of the analysed municipalities, in the adopted research model. 
The analysis made it possible to distinguish groups of municipalities that are similar to each other in terms of tourism development. Six groups were distinguished - corresponding to six types describing the existing tourist facilities in the area of the analysed municipality: type 1 with outstanding conditions; type 2 with very good conditions; type 3 with above good conditions; type 4 with good development conditions, type 5 with average conditions, and type 6 with below average development conditions (Fig. 3).

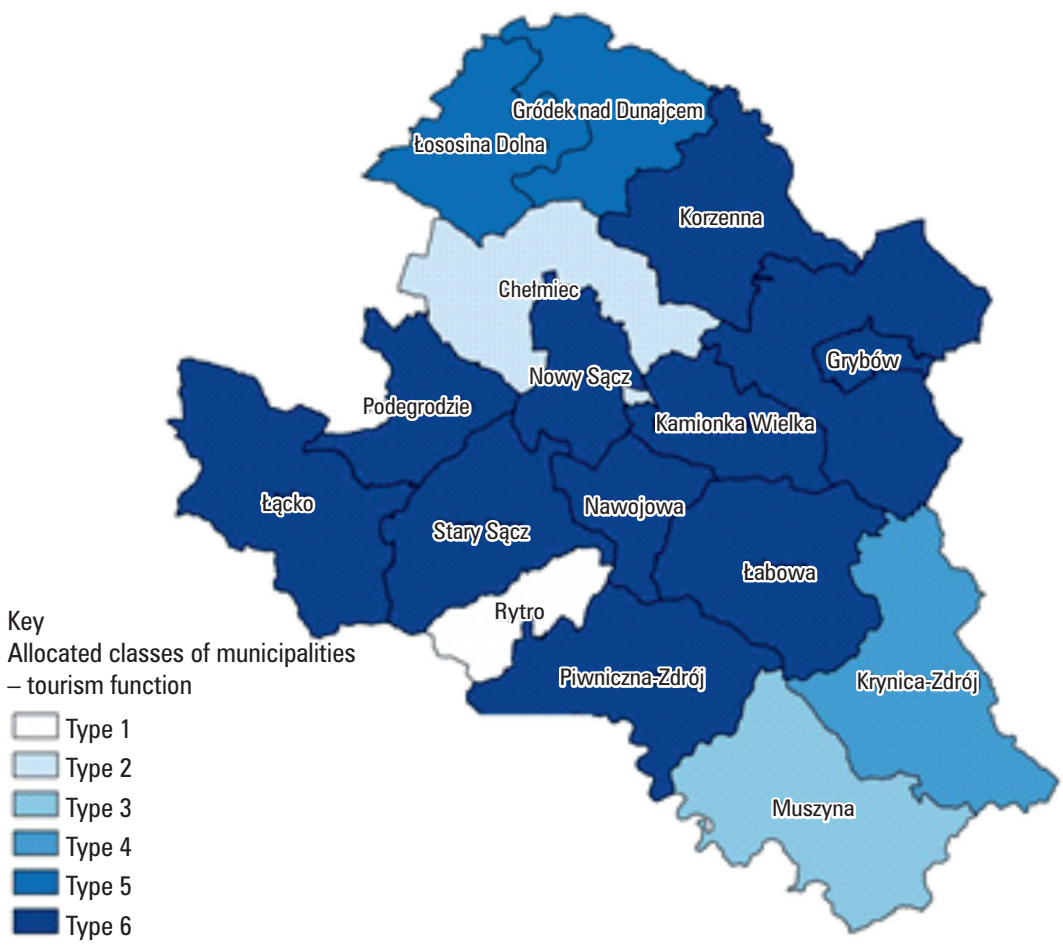

Source: authors' own study

Fig. 3. Subdivision of the municipality into units of similar tourism attractiveness

\section{Conclusions}

The research we have conducted has shown that most municipalities of the Nowy Sącz district are similar to each other in terms of their tourist attractiveness. In each municipality there were a number of tourist attractions - natural and anthropogenic assets, which condition this similarity. At the same time, several municipalities stood out against the rest, including: Rytro, Muszyna, Chełmiec, Krynica-Zdrój, Łososina Dolna and Gródek nad Dunajcem. These municipalities all enjoy a varied terrain, the presence of mineral waters (some also of curative properties), good climatic and land- 
scape conditions as well as large share of forest areas. Therefore, these municipalities have a spa character, which favours the development of tourism. In addition, in the areas of the Rytro, Muszyna and Krynica-Zdrój municipalities, there are numerous tourist trails, ski lifts, as well as objects of sacred architecture (churches, Orthodox churches, chapels) and secular architecture (castles, palaces, manor houses, museums, art galleries, etc.).

Another important group of municipalities is located to the north - namely, the two neighbouring municipalities of Łososina Dolna and Gródek nad Dunajcem. In that area, the Rożnowskie Lake is located, which favours the development of tourism among other things, the creation of appropriate accommodation base, as well as yacht clubs and equipment rental for water sports. The municipalities of Rytro, Muszyna, Chełmiec, Krynica-Zdrój, Łososina Dolna and Gródek nad Dunajcem have been assigned to types 1-5 and they constitute single-element groups (except for group 5, which consists of two elements).

The studies have shown that the final assessment of tourist attractiveness was influenced by such features as: the length of cycling routes and bicycle paths, the number of museums, open-air museums, galleries, memorials, and facilities on the Wooden Architecture Trail, the number of beds/accommodations, as well as the number of stadiums, sports halls, football fields and tennis courts. These features had the greatest impact on the tourism attractiveness of Nowy Sącz district and the city of Nowy Sącz.

\section{References}

Alejziak W. 2000. Turystyka w obliczu wyzwań XXI wieku. Wydawnictwo Albis, Kraków.

Borne H. 1998. Organizacja turystyki. WSiP, Warszawa.

Frankowski Z. 1991. Zastosowanie metod taksonomicznych w badaniach przestrzennych. Agencja Wydawnicza Instytutu Gospodarki Przestrzennej i Komunalnej, Warszawa.

Gaworecki W.W. 2010. Turystyka. Polskie Wydawnictwo Ekonomiczne, Warszawa.

Gawroński K., Prus B., Sołtysik S. 2014. Analiza i ocena warunków rozwoju społeczno-gospodarczego województwa podkarpackiego. Infrastruktura i Ekologia Terenów Wiejskich, IV/2, 1241-1254. http://dx.medra.org/10.14597/infraeco.2014.4.2.092

Gołembski G. (red.) 2005. Kompendium wiedzy o turystyce. Wydawnictwo Naukowe PWN, Warszawa.

Gołembski G. (red.) 2007. Vademecum pilota grup turystycznych. Wydawnictwo Akademii Ekonomicznej w Poznaniu, Poznań.

Grabiński T., Wydymus S., Zeliaś A. 1989. Metody taksonomii numerycznej w modelowaniu zjawisk społeczno-gospodarczych. Wydawnictwo Naukowe PWN, Warszawa.

Heffner K., Gibas P. 2007. Analiza ekonomiczno-przestrzenna. Wydawnictwo Akademii Ekonomicznej w Katowicach, Katowice.

Kornak A. 1997. Ekonomika turystyki. Kujawsko-Pomorskie Studium Edukacyjne, Bydgoszcz.

Kornak A.S., Rapacz A. 2001. Zarządzanie turystyką i jej podmiotami w miejscowości i regionie. Wydawnictwo Akademii Ekonomicznej we Wrocławiu, Wrocław.

Król K., Prus B. 2018. Application of interactive charts in the evaluation of socio-economic development of regions. The case of Poland. Acta Sci. Pol., ser. Formatio Circumiectus, 17(3), 141-151. 
Kurek W. 2008. Turystyka. Wydawnictwo Naukowe PWN, Warszawa.

Łazarek R. 1999. Ekonomika turystyki. Zakład Wydawniczy DrukTur, Warszawa.

Meyer B., Milewski D. (red.) 2009. Strategie rozwoju turystyki w regionie. Wydawnictwo Naukowe PWN, Warszawa.

Middleton V.T.C. 1996. Marketing w turystyce. Polska Agencja Rozwoju Turystyki, Warszawa.

Młodak A. 2006. Analiza taksonomiczna w statystyce regionalnej. Centrum Doradztwa i Informacji, Difin, Warszawa.

Panasiuk A. (red.) 2006. Ekonomika turystyki. Wydawnictwo Naukowe PWN, Warszawa.

Panasiuk A. (red.) 2008. Gospodarka turystyczna. Wydawnictwo Naukowe PWN, Warszawa.

Panek T. 2009. Statystyczne metody wielowymiarowej analizy porównawczej. Oficyna Wydawnicza Szkoły Głównej Handlowej, Warszawa.

Prus B., Król K., Chrobot K. 2018. Analysis of the correlation between socio-economic development and land prices. A study of the Zagnańsk municipality. Acta Sci. Pol., ser. Formatio Circumiectus, 17(2), 87-94.

Przecławski K. 2000. Człowiek a turystyka. Zarys socjologii turystyki. Wydawnictwo Albis, Kraków.

Rapacz A. (red.) 1998. Przedsiębiorstwo turystyczne na rynku. Wydawnictwo Akademii Ekonomicznej we Wrocławiu, Wrocław.

Rapacz A. 1994. Przedsiębiorstwo turystyczne. Podstawy i zasady działania. Wydawnictwo Naukowe PWN, Warszawa.

Sikora J. 2012. Agroturystyka. Przedsiębiorczość na obszarach wiejskich. Wydawnictwo C.H. Beck, Warszawa.

Szubert-Zarzeczny M. 2002. Ekonomiczne podstawy turystyki. Wydawnictwo Akademii Rolniczej we Wrocławiu, Wrocław.

Wodejko S. 1997. Ekonomiczne zagadnienia turystyki. Wydawnictwo Wyższej Szkoły Handlowej, Warszawa.

Wysocki F. 2010. Metody taksonomiczne w rozpoznawaniu typów ekonomicznych rolnictwa i obszarów wiejskich. Wydawnictwo Uniwersytetu Przyrodniczego w Poznaniu, Poznań.

Zeliaś A. (red.) 2000. Taksonomiczna analiza przestrzennego zróżnicowania poziomu życia w Polsce w ujęciu dynamicznym. Wydawnictwo Akademii Ekonomicznej w Krakowie, Kraków.

Prof. dr hab. inż. Krzysztof Gawroński

Uniwersytet Rolniczy w Krakowie

Katedra Gospodarki Przestrzennej i Architektury Krajobrazu

ul. Balicka 253c, 30-198 Kraków

e-mail: krzysztof.gawronski@urk.edu.pl

ORICD: https://orcid.org/0000-0002-9922-7373

Dr inż. Karol Król

Uniwersytet Rolniczy w Krakowie

Katedra Gospodarki Przestrzennej i Architektury Krajobrazu

30-059 Kraków, al. Mickiewicza 24/28

e-mail:k.krol@onet.com.pl

website: http://homeproject.pl

ORICD: https://orcid.org/0000-0003-0534-8471 
Dr inż. Grażyna Gawrońska Uniwersytet Rolniczy w Krakowie

Katedra Melioracji i Kształtowania Środowiska

al. Mickiewicza 24/28, 30-059 Kraków

e-mail: grazyna.gawronska@urk.edu.pl

ORCID: https://orcid.org/0000-0001-8816-1367

Natalia Leśniara

Uniwersytet Rolniczy w Krakowie

Katedra Melioracji i Kształtowania Środowiska

al. Mickiewicza 24/28, 30-059 Kraków 